\title{
Transcription factor regulation and cytokine expression following in vitro infection of primary chicken cell culture with low pathogenic avian influenza virus
}

Haijun Jiang ${ }^{1,2}$, Kangzhen $\mathrm{Yu}^{2}$ and Darrell R Kapczynski ${ }^{*}$

\begin{abstract}
Background: Avian influenza virus (AIV) induced proinflammatory cytokine expression is believed to contribute to the disease pathogenesis following infection of poultry. However, there is limited information on the avian immune response to infection with low pathogenic avian influenza virus (LPAIV).

Methods: To gain a better understanding of the early viral-host interactions of LPAIV in chickens, primary chicken embryo hepatocytes (CEH) were infected with four different LPAIVs of U.S. origin. Kinetics of virus replication, transcription factor (c-Jun, p50 and IRF-3) activation and immune response gene (IL-6, IL-1 beta, IFN-alpha and Mx) expression were studied at four different time points (6, 12, 24 and 48 hours) post infection and compared to non-infected controls.

Results: CEH can support growth of the tested LPAIVs when with trypsin supplementation. All four immune response genes tested were upregulated following infection as were transcription factors c-Jun, p50 and IRF-3. Amplification of these genes was dependant on virus replication (e.g. inclusion of trypsin), such that immune response genes and transcription factors were upregulated as viral titers increased.
\end{abstract}

Conclusion: The results of these studies demonstrate the requirement of virus replication for innate immune regulation and broaden our understanding of transcription factor responses related to LPAIV infection in chickens.

Keywords: Avian influenza virus, Chicken, Cytokine, Transcription factor

\section{Introduction}

Avian influenza (AI) infection in poultry can result in high morbidity and mortality, and negatively affect international trade [1]. AIV can be categorized into 16 different hemagglutinin (HA) subtypes (H1-H16) and 9 different neuraminidases (N1-N9) subtypes which can occur in many combinations [2]. During the past decade, low pathogenic (LP) AIV has caused considerable economic loss due to decreased production, increased morbidity and increase the cost of vaccination in poultry industry [3]. LPAI viruses have the potential to evolve into highly pathogenic (HP) AIV and this has been documented in many poultry outbreaks. However, only the

\footnotetext{
* Correspondence: darrell.kapczynski@ars.usda.gov

${ }^{1}$ Exotic and Emerging Avian Disease Research Unit, Southeast Poultry Research Laboratory, Agricultural Research Service, USDA, 934 College Station Road, Athens, GA 30605, Greece

Full list of author information is available at the end of the article
}

H5 and H7 subtypes, have been associated with HPAI mutation $[4,5]$. This has led to a new proposed definition of avian influenza to extend all infections caused by $\mathrm{H} 5$ and $\mathrm{H} 7$ viruses regardless of their virulence as notifiable avian influenza (NAI) [6]. The H9N2 subtype was first reported to infect turkeys in the United States in 1966 and has seriously affected the poultry industry of the Asia and Middle East since the mid-1990s [7-9]. This subtype is considered one of the most likely candidates to cause a new influenza pandemic in humans [10]. In 1999 and 2003, the reports of H9N2 AIV infections of humans in Hong Kong dramatically attracted the attention of the scientific community $[11,12]$.

The innate immune system response is the first line of defense and limits early virus replication [13]. Cytokines are important immune mediators of innate and acquired immunity responsible for initiating, amplifying and regulating 
inflammation in response to pathogenic infection $[14,15]$. Knowledge of the innate immune recognition of AIV is crucial to understanding the viral pathogenesis in birds. Recognition of pathogen-associated molecular patterns (PAMPs) by host pattern recognition receptors (PRRs) represents a critical step in innate immune responses [16]. Proper communication between host cells and pathogen via PAMPs and PRRs initiates signal transduction pathways which in turn induces the expression of cytokines aimed at controlling pathogens [17].

Recognition of the virus through PRRs, such as retinoicacid inducible gene I (RIG-I), melanoma differentiationassociated gene 5 (MDA-5) and toll-like receptors (TLRs) induces activation and translocation of transcription factors to nucleus, including activator protein-1 (AP-1), interferon regulatory (IRF) factor 3 (IRF-3) and nuclear factor-kappa $\beta$ $(\mathrm{NF}-\mathrm{k} \beta)$, which collaborate to induce transcription of various cytokines such as alpha/beta interferon, leading to clearance of the infectious pathogens [18]. Understanding the mechanisms that regulate innate immune responses to AIV is of key importance to develop novel virus-based therapeutic strategies. In mammals, studies have been carried out to examine the transcription factors signaling pathways after infection with influenza virus, however, in chicken very little is known [19]. Although no commercial kit exists to examine chicken cellular transcription factors, previous reports have confirmed the cross-reactivity between birds and mammals in c-Jun, IRF-3 and p50 [20-24].

Lesions and viral antigen distribution are frequently observed in chicken liver infected with AIV [25-27]. Primary chicken embryo hepatocytes (CEHs) have been used for virus propagation, detection, and subsequent vaccine production [28-30]. Here we used primary CEHs which are readily used to study AIV infections because of their high susceptibility, thus are suitable to detect changes in gene expression early in the course of infection under controlled conditions. In this study, we compared viral replication, virus-induced cytokine gene expression and activation of cellular transcription factors associated with low pathogenic H5N3, H5N9, H7N2 and H9N2 viruses infection of CEH. The objective was to understand the early immune and cellular responses to broaden our understanding of the molecular mechanisms related to LPAIV infection in chicken.

\section{Results}

\section{Growth kinetics of viruses on $\mathrm{CEH}$}

To investigate the replication of different virus strains, CEHs were infected with H5N9, H5N3, H7N2 and $\mathrm{H} 9 \mathrm{~N} 2$ viruses at MOI of 1 and the viral titers in the supernatants were determined as $\log 10 \mathrm{EID} 50 / \mathrm{ml}$. Comparison of the growth characteristics of H5N9, H5N3, H7N2 and H9N2 viruses in CEHs with or without trypsin supplementation in the medium after infection are shown in Figure 1. CEH cannot efficient support growth

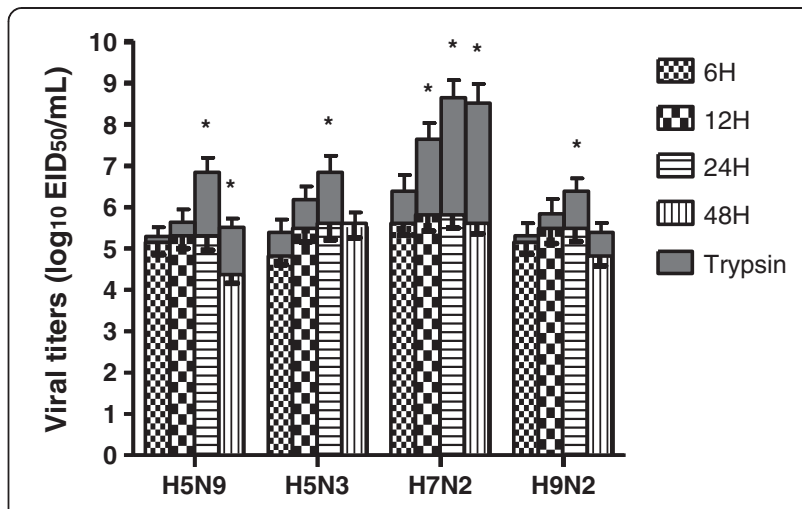

Figure 1 Kinetics of CEH infection by H5N9, H5N3, H7N2 and H9N2 viruses. Cells were infected at $\mathrm{MOI}$ of 1 and supplemented with $1 \mu \mathrm{g} / \mathrm{ml}$ trypsin or without trypsin in the medium. The viral titers in supernatants collected at 6, 12, 24 and 48 hpi were determined as $\log 10$ EID50/ml. The patterns bars represent the viral titers achieved without the use of supplemental trypsin. The gray bar stacked on top represents the increase in the viral titers with the addition of supplemental trypsin. Error bars show standard deviation of the mean, $n=3$. *Indicates the difference $(P<0.05)$ between the supplemented with and without trypsin group.

of the above viruses without supplemental trypsin in the medium, presumably because $\mathrm{CEH}$ cannot produce trypsin-like protease. But after with $1 \mu \mathrm{g} / \mathrm{ml}$ trypsin supplementation in the medium after infection, viral titers increasing until $24 \mathrm{hpi}$, especially $\mathrm{H} 7 \mathrm{~N} 2$ virus has a significant increase. The viral titers for H5N9, H5N3, $\mathrm{H} 7 \mathrm{~N} 2$ and $\mathrm{H} 9 \mathrm{~N} 2$ at 24 hpi were $6.8,6.8,8.6$, and 6.4 log10 EID50 per ml, respectively.

\section{Pro-inflammatory IL-6/IL-1 $\beta$ expression following virus growth on $\mathrm{CEH}$}

The influence of LPAIV on pro-inflammatory IL-6/IL-1 $\beta$ cytokines expression in $\mathrm{CEH}(6,12,24$ and $48 \mathrm{hpi})$ is shown in Figure 2. The expression of IL-6 was similar in CEH with trypsin supplementation after infection at the early stage of viral infection, with a low expression level at $6 \mathrm{hpi}$ and then a slight increase at 12 hpi. However, IL-6 was significantly upregulated at 24 and 48 hpi. H7N2 virus demonstrated the highest expression level of IL-6 expression at 7.9-fold increase compared to sham-infected cells at $48 \mathrm{hpi}$.

IL-1 $\beta$ expression was similar in CEH with trypsin supplementation with a peak at 24 hpi and decreased at 48 hpi. H7N2 also demonstrated the highest level of expression (8.8-fold) at 24 hpi. Interestingly, the IL- 6 and IL-1 $\beta$ expression in $\mathrm{CEH}$ without trypsin after infection were far lower compared to expression observed with trypsin.

\section{Interferon- $a$ and Myxovirus (Mx) expression following virus growth on $\mathrm{CEH}$}

The induction of IFN- $\alpha$ and Mx expression in CEH (6, 12, 24 and $48 \mathrm{hpi}$ ) following LPAIV infection is shown in Figure 3. The results show that IFN- $\alpha$ and $\mathrm{Mx}$ 


\section{No Trypsin}

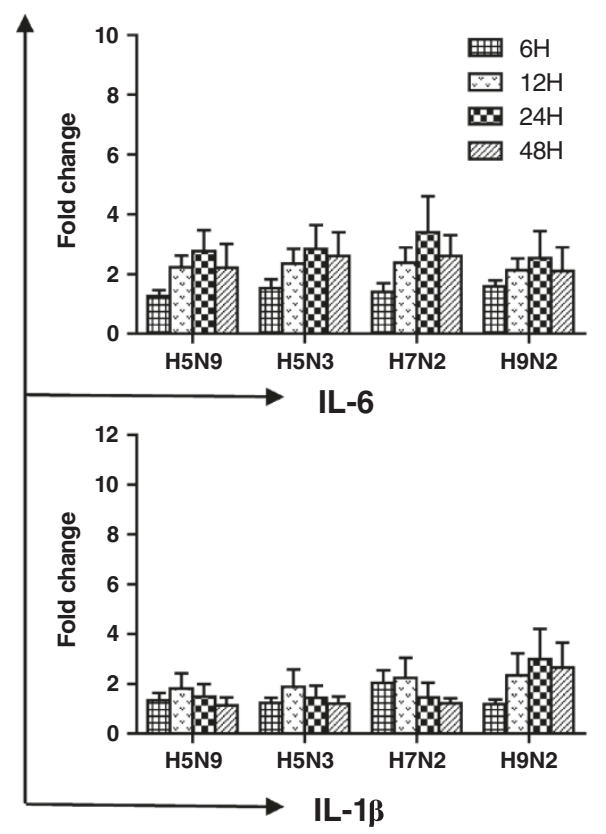

Trypsin
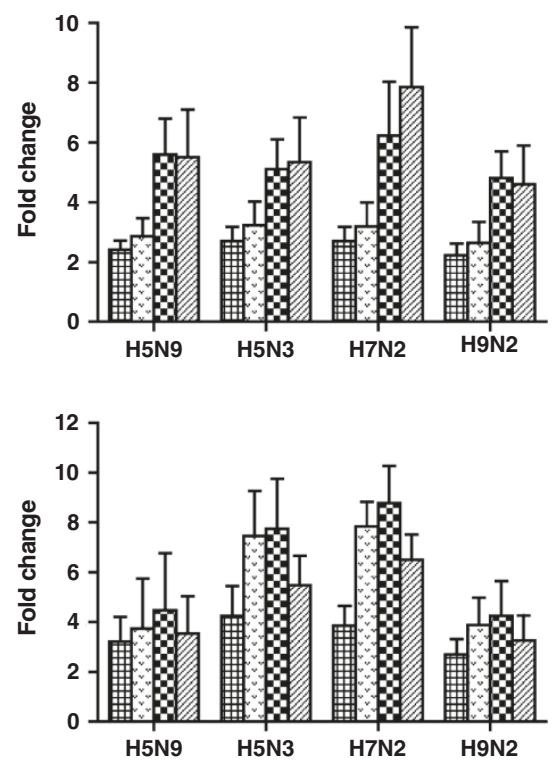

Figure 2 Pro-inflammatory IL-6/IL-1 $\beta$ mRNA expression of CEH infection by H5N9, H5N3, H7N2 and H9N2 viruses. Cells were infected for different time periods with LPAIV at $\mathrm{MOI}$ of 1 and supplemented with $1 \mu \mathrm{g} / \mathrm{ml}$ trypsin or without trypsin in the medium. Total RNA was isolated and quantitated using QRRT-PCR. The horizontal axis represents virus. The vertical axis represents the fold change. Error bars represent standard deviation across each condition performed in triplicate.

No Trypsin

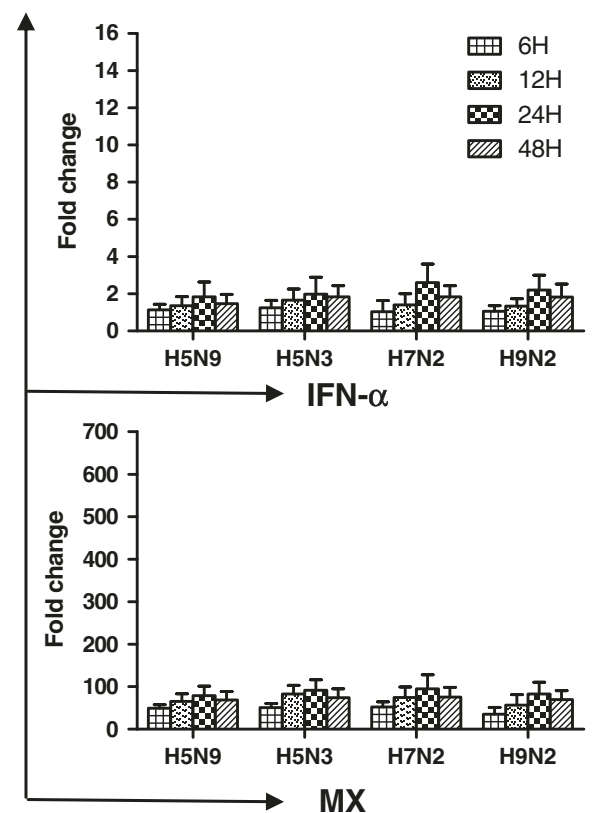

Trypsin
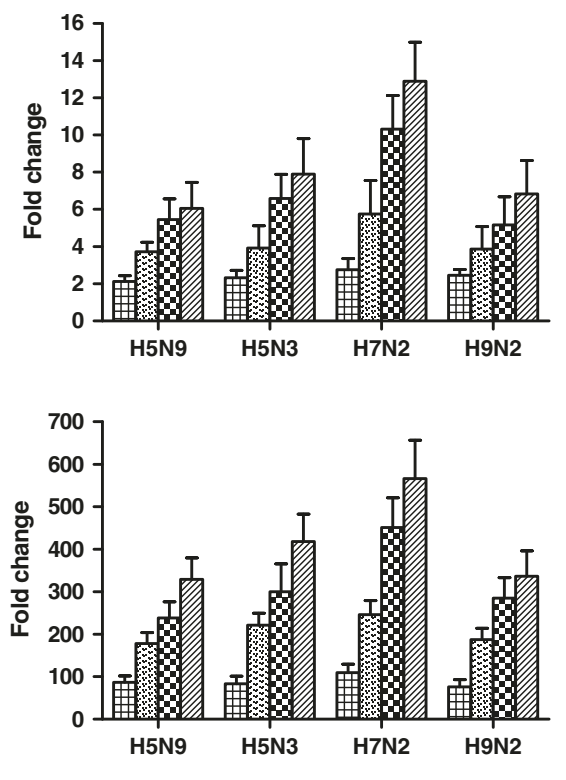

Figure 3 Interferon-a/Mx mRNA expression of CEH infection by H5N9, H5N3, H7N2 and H9N2 viruses. Cells were infected for different time periods with LPAIVs at MOI of 1 and supplemented with $1 \mu \mathrm{g} / \mathrm{ml}$ trypsin or without trypsin in the medium. Total RNA was isolated and quantitated using QRRT-PCR. The horizontal axis represents virus. The vertical axis represents the fold change. Error bars represent standard deviation across each condition performed in triplicate. 
expression pattern in the CEH with trypsin after infection are similar, with isolates inducing upregulated expression throughout the experiment. A significant increase was observed when trypsin was added compare to without trypsin. The H7N2 virus was observed to induce much higher IFN- $\alpha$ and Mx expression on CEH with trypsin than other viruses.

\section{Activation of c-Jun, p50 and IRF-3 by LPAIVs}

Infection of the CEH with LPAIV induced an increase in DNA-binding transcription factors, c-Jun, p50 and IRF3 , most notably with trypsin supplementation (Figure 4). The activation patterns of c-Jun and p50 were similar in $\mathrm{CEH}$ with a peak at $24 \mathrm{hpi}$ and decreased levels at 48 hpi. Likewise, LPAIV induced an increase in IRF-3 with all isolates upregulating expression throughout the experiment. The $\mathrm{H} 7 \mathrm{~N} 2$ virus induced much higher increase in c-Jun, p50 and IRF-3 on CEH than the other viruses.

\section{Discussion}

In these studies we compared the effects of different LPAIV on transcription factor activation and immune response gene expression in primary $\mathrm{CEH}$. For the first time we demonstrate that chicken cells increase activation of c-Jun, IRF-3 and p50 transcription factors after AIV infection, which correlated with increased cytokine expression. Transcription factor activation and immune response gene induction also correlated with virus growth.

Early after infection, viruses are capable of triggering a series of intracellular events which may be accompanied by changes in host gene expression and activation of a variety of intracellular signaling pathways that are in part exploited by the virus to ensure efficient replication [31]. In mammals, influenza virus infection and replication result in the production of multiple proinflammatory, chemotactic and antiviral cytokines [32,33]. Cytokine gene expression are associated with the activation of a
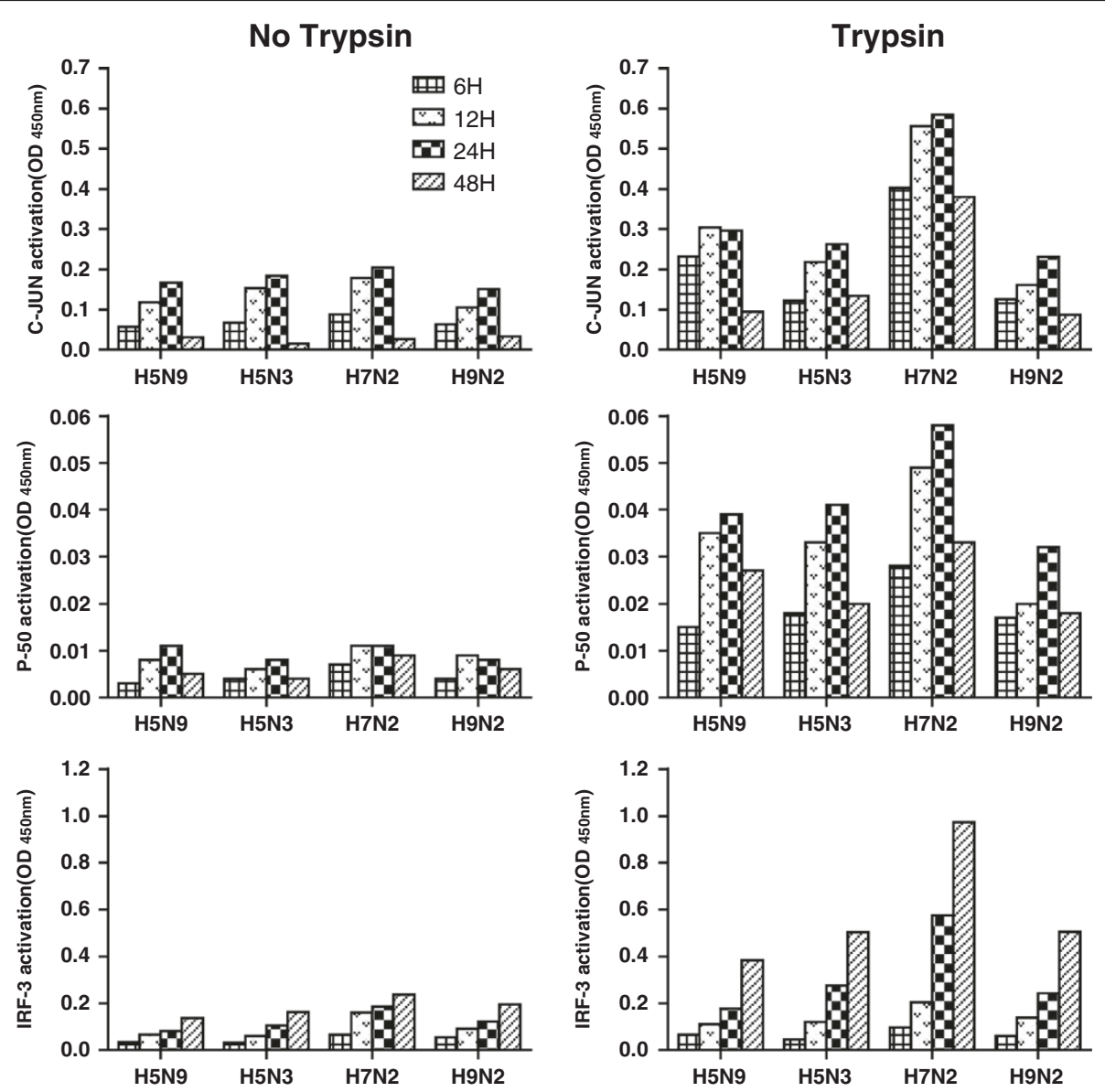

Figure 4 C-Jun, p50 and IRF-3 activity in CEH in response to LPAIVs. Cells were infected for different time periods with LPAIVs at MOI of 1 and supplemented with $1 \mu \mathrm{g} / \mathrm{ml}$ trypsin or without trypsin in the medium. Cell lysates $(10 \mu \mathrm{g} / \mathrm{ml})$ were tested for binding of the activated c-Jun, IRF-3 and p50 subunits using the Trans-Am ELISA kit. The results are expressed as specific binding (absorbance measured in the presence of the mutated oligonucleotides minus that measured in the presence of the wild-type oligonucleotides) according to the manufacturer's instructions and are compared to non-infected control. 
series of signal transducing molecules, such as AP-1 [34], STAT [35] and IRF [36], in influenza virus infected cells. However, our understanding of which transcription factors are involved in the cytokine gene expression mounted by the chicken cells to AIV is unknown.

When CEHs were infected with LPAIVs in the presence of trypsin, viral titers were increased, especially the H7N2 virus. This result suggests that LPAIV cannot replicate very well in $\mathrm{CEH}$ without exogenous trypsin. This is consistent with previous reports that report a need for trypsin-like proteases to cleave the hemagglutinin protein into the HA1 and HA2 subunits, which is required for the virus to be infectious $[37,38]$.

Infection with HPAI in birds and mammals is associated with severe pathology and increased mortality. One possible hypothesis for the cause of death in mammals due to HPAI infection is the acute induction of high levels of inflammatory cytokines, a so called cytokine storm [39-41]. The results of our study also demonstrate increased expression of pro-inflammation cytokines, IL6 , IL- $1 \beta$ and IFN- $\alpha$, following LPAIV infection in vitro. These results correlate with previous studies which have also demonstrated increased pro-inflammatory cytokines expression following LPAIV infection [42,43].

Interferon regulatory factors are a family of DNAbinding proteins involved in mediating the cellular immune response following viral infection. In mammals influenza virus infection induces activation of IRF-3 signaling [44-46], however its role in chicken immunity remains in question. It has been reported that chicken IRF-3 is activated by type I and type II IFN and its binding specificity has been demonstrated $[47,48]$. More recently, Liniger reported that chicken IRF-3 was required for virus-mediated type I IFN induction in DF-1 cells [49]. In our study, we also demonstrate increased IRF-3 production after infection with all isolates of LPAIV tested.

The transcription factor NF- $\mathrm{k} \beta$ is known as a major regulator of the inflammatory response [50,51]; however, its role in avian influenza virus replication and virusinduced immune response is ill-defined. In recent studies, NF-kB subunit p50 knockout cells demonstrated that activation of p50 is obsolete for production of interferon stimulated genes (ISG) upon virus infection [52] and that p50 is the predominant negative regulator of ISGs in the context of influenza virus infection [53]. In our studies, we observed that infection with LPAIV induced an increase in p50 DNA binding after infection. Furthermore, the increased activation of p50 correlated with a resulting increase of proinflammatory cytokines. A previous study has reported that treatment of chicken heterophils with either flagellin or lipopolysaccharide induced a significant increase in DNA binding by the NF- $\mathrm{B}$ family member p50 [54]. These results demonstrate the significant role of p50 activation in inducing the expression of pro-inflammatory cytokines in chicken following infection.

In mammals, influenza virus infection induces transcription factor c-Jun and AP-1 activation and signaling, and helps to generate many of the biological effects of IFN production [34,44-46,55-59]. However in gallinaceous birds very little was known about the signaling pathways after infection with AIV. We observed an increase in c-Jun activation after infection of CEH with LPAIV. The increased transcription factor activation correlated with increased proinflammatory response, these sequential processes suggest that c-Jun and IRF-3 likely mediate the induction of IL-6, IL- $1 \beta$ and IFN- $\alpha$ gene expression. Similar timing of transcription factor activation and cytokine gene expression was found in mammalian cells [34,45]. To our knowledge these findings confirm for the first time, that similar to mammal cells, infection of chicken cells with LPAIV increases protein expression of host DNA-binding transcription factors.

\section{Conclusion}

Our results demonstrate $\mathrm{CEH}$ can efficiently support growth of the LPAIV with trypsin supplementation in the medium after infection, especially the $\mathrm{H} 7 \mathrm{~N} 2$ virus. After infection all immune response genes tested were upregulated and the transcription factors, c-Jun, IRF-3 and $\mathrm{p} 50$, were also increased compared to sham-infected controls. These data will broaden our understanding the avian immune response to infection with LPAIV and has implications for strategies that target the innate immune system for improving resistance to avian influenza.

\section{Materials and methods}

\section{Cells isolation and culture}

Primary CEHs were isolated from 14-day-old white leghorn chicken embryos of Specific Pathogen Free (SPF) eggs as previously described [60] and were cultured at $37^{\circ} \mathrm{C}$ and $5 \% \mathrm{CO} 2$ in Dulbecco's modified Eagle's medium (DMEM) supplemented with $10 \%$ fetal bovine serum (Invitrogen, CA,USA), $2 \mathrm{mM}$ glutamine and antibiotics (final concentration: penicillin, $100 \mathrm{U} / \mathrm{ml}$; streptomycin, $100 \mu \mathrm{g} / \mathrm{ml})$. Cell viability was assessed by the Trypan Blue exclusion test and was not less than $90 \%$ for each preparation. Contamination by non-hepatocyte cells was minimal by microscopic examination. The cells were counted and suspensions were diluted to $2 \times 106$ viable (dye-excluding) cells per ml. The cells were distributed into $60 \times$ $15 \mathrm{~mm}$ culture dishes (Becton Dickinson, NJ, USA) for virus growth kinetics and RNA extraction or nuclear extraction, respectively. For each experiment, cells were prepared on the same day and under the same conditions.

\section{Virus and cell culture infection}

A/turkey/Wisconsin/68 (H5N9), A/chicken/Texas/1672804/02 (H5N3), A/turkey/Virginia/158512/02 (H7N2) and A/ 
chicken/NJ/12220/97 (H9N2) LPAI viruses were propagated in allantoic cavities of 9-11 day of embryonation SPF chicken eggs. Viral titers were determined as previously described [61]. All experiments using infectious virus were conducted in bio-safety level 2 (BSL-2) facilities at the Southeast Poultry Research Laboratory (SEPRL), Agricultural Research Service, United States Department of Agriculture (USDA).

\section{Virus growth curves}

The growth curves of the viruses were determined by virus titration of cell culture supernatants at different time points after infection of primary CEH. Briefly, cells were infected with each virus at a multiplicity of infection (MOI) of one in DMEM, negative control cells were set up identically but without the addition of virus. Culture dishes were gently rocked every $15 \mathrm{~min}$ for $1 \mathrm{~h}$ at $37^{\circ} \mathrm{C}$, non-adsorbed viruses were removed and the cells were washed with sterile phosphate buffered saline (PBS). DMEM supplemented with $2 \%$ FBS or $1 \mu \mathrm{g} / \mathrm{mL}$ TPCK trypsin (Sigma-Aldrich, St. Louis, MO) for CEHs were added per dish and the dishes were incubated at $37^{\circ} \mathrm{C}$ and $5 \% \mathrm{CO} 2$. At $6,12,24$, and 48 hours postinfection (hpi), supernatants were collected and stored at $-80^{\circ} \mathrm{C}$ until used for titrations in SPF embryos. Virus titers were determined using the method of Reed and Muench and expressed as 50\% egg infectious dose (EID50) [62].

\section{Isolation of RNA and quantification of cytokine gene expression}

Total RNA was isolated from infected and control cells at each time point using the RNeasy mini kit (Qiagen) in accordance with the manufacturer's instructions, and treated with RNase-free DNase I (Invitrogen) to remove genomic DNA. All RNA samples were checked by using a Nanodrop spectrophotometer (Nanodrop Technologies, Wilmington, DE). Relative cytokine mRNA expression in the abovementioned cells were examined by quantitative RT-PCR. Interleukin (IL)- $1 \beta$, IL- 6 , IFN- $\alpha$, and $\mathrm{Mx}$ expression were determined as previously described $[15,63]$. Briefly, quantitative PCR was performed for each sample in triplicate in a total volume of $25 \mu \mathrm{l}$, consisting of $12.5 \mu \mathrm{l}$ iQ SYBR Green supermix (Bio-Rad Laboratories, CA, USA) with $1 \mu \mathrm{l}$ of each primer at concentration of $10 \mathrm{pmol} / \mu \mathrm{l}, 0.5 \mu \mathrm{l}$ iScript reverse transcriptase, $5 \mu \mathrm{l}$ RNase/DNase-free water, and $5 \mu \mathrm{l}$ diluted RNA. PCR conditions were the same for each targeted gene and are as follows: $10 \mathrm{~min}$ at $50^{\circ} \mathrm{C}, 95^{\circ} \mathrm{C}$ for $5 \mathrm{~min}$, followed by 45 cycles of $95^{\circ} \mathrm{C}$ for $10 \mathrm{~s}$ and $58^{\circ} \mathrm{C}$ for $30 \mathrm{~s}$. For each reaction, melting curves were analyzed to determine the specificity of each gene. Primers were derived from previously published sequence and synthesized by Integrated DNA Technologies [64]. Sequences are as follows (forward, reverse): IL-6 (5'-GCGAGAACAG CATGGAGATG-3', 5'-CTGTTCGCCTTTCAGACCTAC3'); IL-1 $\beta$ (5'-ACATGTCGTGTGTGATGA-3', 5'-GCTT CATCTTCTACCGCCTG-3'); IFN- $\alpha$ (5'-GACAGCCA ACGCCAAAGC-3', 5'-AATGCTTGAGCAGCAGCGA C-3'); Mx (5'-CAGGACATCAACGACAATCT-3', 5'TTGCCAGATGAGGGATAGTA-3') and 28S (5'-GGC GAAGCCAGAGGAAACT-3', 5'-GACGACCGATTTGCA CGTC-3'). RNA from individual cell samples was normalized using $28 \mathrm{~S}$ house-keeping gene. For each gene, amplification was verified using four 10-fold serial dilutions of standard spleen cell RNA in the same PCR run. Expression was determined by the standard curve method [65]. Data are expressed as fold change in cytokine messenger RNA (mRNA) levels in infected groups compared with those from uninfected groups.

\section{c-Jun, IRF-3 and p50 activation analysis}

The ELISA-based Trans-Am transcription factor kits (Active Motif, Carlsbad, CA, USA) were used to detect and quantify c-Jun, IRF-3 and p50 activation as previously described [54]. The 96-well plates are contain immobilized oligonucleotides containing transcription response elements for c-Jun (5'-TGAGTCA-3'), NF- $\mathrm{k} \beta$ p50 consensus binding site (5'-GGGACTTTCC-3') or IRF consensus binding site (5'-GAAACTGAAACT-3'). The active forms of the subunits for c-Jun or p50 or IRF-3 in nuclear extracts can be detected using specific antibodies for epitopes that are accessible only when the nuclear factors are activated and bound to their target DNA. Preparation of nuclear extract was done according to the manufacturer's instructions. The specificity of the assays was checked by measuring the ability of soluble wild type or mutated c-Jun, p50 and IRF-3 oligonucleotides to inhibit binding. The results are expressed as specific binding (absorbance measured in the presence of the mutated oligonucleotides minus that measured in the presence of the wild-type oligonucleotides) according to the manufacturer's instructions.

\section{Statistical analyses}

Data are expressed as the mean \pm standard deviation. Statistical differences were analyzed with Tukey one-way ANOVA using Prism 5 (GraphPad Co., San Diego, CA).

\section{Competing interests}

The authors declare that they have no competing interests.

\section{Authors' contributions}

$\mathrm{HJ}$ and DRK carried out virus growth on cell culture as well as RRT-PCR for avian cytokines. HJ performed transcription factor analysis. KY participated in study design and coordination. HJ and DRK wrote the manuscript. All authors read and approved the final manuscript.

\section{Acknowledgments}

The authors wish to thank Cam Greene and Aniko Zsak for expert technical help. This research was supported by USDA, ARS, CRIS project 6612-32000-062. 
Author disclosure statement

The authors declare that they have no competing interests.

\section{Author details}

${ }^{1}$ Exotic and Emerging Avian Disease Research Unit, Southeast Poultry Research Laboratory, Agricultural Research Service, USDA, 934 College Station Road, Athens, GA 30605, Greece. ${ }^{2}$ Key Laboratory of Zoonosis of Ministry of Agriculture, College of Veterinary Medicine and State Key Laboratory of Agrobiotechnology, China Agricultural University, Beijing, People's Republic of China.

Received: 16 July 2013 Accepted: 14 November 2013

Published: 19 November 2013

\section{References}

1. Kapczynski DR, Liljebjelke K, Kulkarni G, Hunt H, Jiang HJ, Petkov D: Cross reactive cellular immune responses in chickens previously exposed to low pathogenic avian influenza. BMC Proc 2011, 5(4):S13.

2. Swayne DE, Kapczynski D: Strategies and challenges for eliciting immunity against avian influenza virus in birds. Immunol Rev 2008 225:314-331.

3. Kapczynski DR, Swayne DE: Influenza vaccines for avian species. Curr Top Microbiol Immunol 2009, 333:133-152

4. Veits J, Weber S, Stech O, Breithaupt A, Graber M, Gohrbandt S, Bogs J Hundt J, Teifke JP, Mettenleiter TC, Stech J: Avian influenza virus hemagglutinins $\mathrm{H} 2, \mathrm{H} 4, \mathrm{H} 8$, and $\mathrm{H} 14$ support a highly pathogenic phenotype. Proc Natl Acad Sci USA 2012, 109:2579-2584.

5. Capua I, Alexander DJ: Avian influenza infections in birds-a moving target. Influenza Other Respi Viruses 2007, 1:11-18.

6. Capua I, Alexander DJ: Avian influenza: recent developments. Avian Pathol 2004, 33:393-404.

7. Fusaro A, Monne I, Salviato A, Valastro V, Schivo A, Amarin NM, Gonzalez C, Ismail MM, Al-Ankari AR, Al-Blowi MH, et al: Phylogeography and evolutionary history of reassortant $\mathrm{H} 9 \mathrm{~N} 2$ viruses with potential human health implications. J Virol 2011, 85:8413-8421.

8. Homme PJ, Easterday BC: Avian influenza virus infections: I: Characteristics of influenza A-turkey-Wisconsin-1966 virus. Avian Dis 1970, 14:66-74.

9. Soda K, Asakura S, Okamatsu M, Sakoda Y, Kida H: H9N2 influenza virus acquires intravenous pathogenicity on the introduction of a pair of dibasic amino acid residues at the cleavage site of the hemagglutinin and consecutive passages in chickens. Virol J 2011, 8:64.

10. Qiao C, Liu Q, Bawa B, Shen H, Qi W, Chen Y, Mok CK, Garcia-Sastre A, Richt JA, Ma W: Pathogenicity and transmissibility of reassortant $\mathrm{H} 9$ influenza viruses with genes from pandemic H1N1 virus. J Gen Virol 2012, 93:2337-2345.

11. Butt KM, Smith GJ, Chen H, Zhang LJ, Leung YH, Xu KM, Lim W, Webster RG, Yuen KY, Peiris JS, Guan Y: Human infection with an avian H9N2 influenza A virus in Hong Kong in 2003. J Clin Microbio/ 2005, 43:5760-5767.

12. Saito T, Lim W, Suzuki T, Suzuki Y, Kida H, Nishimura SI, Tashiro M: Characterization of a human H9N2 influenza virus isolated in Hong Kong. Vaccine 2001, 20:125-133.

13. Maecker H, Varfolomeev E, Kischkel F, Lawrence D, LeBlanc H, Lee W, Hurst S, Danilenko D, Li J, Filvaroff E, et al: TWEAK attenuates the transition from innate to adaptive immunity. Cell 2005, 123:931-944.

14. Lowenthal JW, Lambrecht B, van den Berg TP, Andrew ME, Strom AD, Bean AG: Avian cytokines - the natural approach to therapeutics. Dev Comp Immunol 2000, 24:355-365.

15. Jiang $H$, Yang $H$, Kapczynski DR: Chicken interferon alpha pretreatment reduces virus replication of pandemic $\mathrm{H} 1 \mathrm{~N} 1$ and $\mathrm{H} 5 \mathrm{~N} 9$ avian influenza viruses in lung cell cultures from different avian species. Virol J 2011, 8:447.

16. Meylan E, Tschopp J, Karin M: Intracellular pattern recognition receptors in the host response. Nature 2006, 442:39-44.

17. Janeway CA Jr, Medzhitov R: Innate immune recognition. Annu Rev Immunol 2002, 20:197-216

18. Zhong B, Tien $P$, Shu HB: Innate immune responses: crosstalk of signaling and regulation of gene transcription. Virology 2006, 352:14-21.

19. Bowie $A G$, Unterholzner L: Viral evasion and subversion of patternrecognition receptor signalling. Nat Rev Immunol 2008, 8:911-922.

20. Bos TJ, Monteclaro FS, Mitsunobu F, Ball AR Jr, Chang CH, Nishimura T, Vogt PK: Efficient transformation of chicken embryo fibroblasts by c-Jun requires structural modification in coding and noncoding sequences. Genes Dev 1990, 4:1677-1687.
21. Capobianco AJ, Chang D, Mosialos G, Gilmore TD: p105, the NF-kappa B p50 precursor protein, is one of the cellular proteins complexed with the v-Rel oncoprotein in transformed chicken spleen cells. J Virol 1992, 66:3758-3767.

22. Grant CE, Vasa MZ, Deeley RG: CIRF-3, a new member of the interferon regulatory factor (IRF) family that is rapidly and transiently induced by dsRNA. Nucleic Acids Res 1995, 23:2137-2146.

23. Saitoh T, Tun-Kyi A, Ryo A, Yamamoto M, Finn G, Fujita T, Akira S, Yamamoto N, Lu KP, Yamaoka S: Negative regulation of interferon-regulatory factor 3-dependent innate antiviral response by the prolyl isomerase Pin1. Nat Immunol 2006, 7:598-605.

24. Takahasi K, Suzuki NN, Horiuchi M, Mori M, Suhara W, Okabe Y, Fukuhara Y, Terasawa H, Akira S, Fujita T, Inagaki F: X-ray crystal structure of IRF-3 and its functional implications. Nat Struct Biol 2003, 10:922-927.

25. Kapczynski DR, Pantin-Jackwood M, Guzman SG, Ricardez Y, Spackman E, Bertran K, Suarez DL, Swayne DE: Characterization of the 2012 highly pathogenic avian influenza H7N3 virus isolated from poultry in an outbreak in Mexico: pathobiology and vaccine protection. J Virol 2013, 87:9086-9096

26. Post J, de Geus ED, Vervelde L, Cornelissen JB, Rebel JM: Systemic distribution of different low pathogenic avian influenza (LPAI) viruses in chicken. Virol J 2013, 10:23.

27. van Riel D, van den Brand JM, Munster VJ, Besteboer TM, Fouchier RA, Osterhaus AD, Kuiken T: Pathology and virus distribution in chickens naturally infected with highly pathogenic avian influenza A virus (H7N7) During the 2003 outbreak in The Netherlands. Vet Pathol 2009, 46:971-976.

28. Lee J, Foster DN, Bottje WG, Jang HM, Chandra YG, Gentles LE, Kong BW: Establishment of an immortal chicken embryo liver-derived cell line. Poult Sci 2013, 92:1604-1612.

29. Lukert PD: Immunofluorescence of avian infectious bronchitis virus in primary chicken embryo kidney, liver, lung, and fibroblast cell cultures. Arch Gesamte Virusforsch 1966, 19:265-272.

30. Allan GM, McNulty MS: A direct immunofluorescence test for the rapid detection of avian influenza virus antigen in tissue impression smears. Avian Pathol 1985, 14:449-460.

31. Julkunen I, Sareneva T, Pirhonen J, Ronni T, Melen K, Matikainen S: Molecular pathogenesis of influenza $A$ virus infection and virus-induced regulation of cytokine gene expression. Cytokine Growth Factor Rev 2001, 12:171-180

32. Kaufmann A, Salentin R, Meyer RG, Bussfeld D, Pauligk C, Fesq H, Hofmann $P$, Nain $M$, Gemsa D, Sprenger $H$ : Defense against influenza A virus infection: essential role of the chemokine system. Immunobiology 2001, 204:603-613.

33. Ma W, Belisle SE, Mosier D, Li X, Stigger-Rosser E, Liu Q, Qiao C, Elder J, Webby R, Katze MG, Richt JA: 2009 pandemic H1N1 influenza virus causes disease and upregulation of genes related to inflammatory and immune responses, cell death, and lipid metabolism in pigs. J Virol 2011, 85:11626-11637.

34. Ludwig S, Ehrhardt C, Neumeier ER, Kracht M, Rapp UR, Pleschka S: Influenza virus-induced AP-1-dependent gene expression requires activation of the JNK signaling pathway. J Biol Chem 2001, 276:10990-10998.

35. Bot A, Rodrigo E, Wolfe T, Bot S, Von Herrath MG: Infection-triggered regulatory mechanisms override the role of STAT 4 in control of the immune response to influenza virus antigens. J Virol 2003, 77:5794-5800.

36. Ronni T, Sareneva T, Pirhonen J, Julkunen I: Activation of IFN-alpha, IFNgamma, MxA, and IFN regulatory factor 1 genes in influenza A virusinfected human peripheral blood mononuclear cells. J Immunol 1995, 154:2764-2774.

37. Chen J, Lee KH, Steinhauer DA, Stevens DJ, Skehel JJ, Wiley DC: Structure of the hemagglutinin precursor cleavage site, a determinant of influenza pathogenicity and the origin of the labile conformation. Cell 1998, 95:409-417.

38. Steinhauer DA: Role of hemagglutinin cleavage for the pathogenicity of influenza virus. Virology 1999, 258:1-20.

39. Salomon R, Hoffmann E, Webster RG: Inhibition of the cytokine response does not protect against lethal H5N1 influenza infection. Proc Natl Acad Sci USA 2007, 104:12479-12481.

40. Cameron CM, Cameron MJ, Bermejo-Martin JF, Ran L, Xu L, Turner PV, Ran R, Danesh A, Fang Y, Chan PK, et al: Gene expression analysis of host innate immune responses during Lethal H5N1 infection in ferrets. J Virol 2008, 82:11308-11317. 
41. Zheng BJ, Chan KW, Lin YP, Zhao GY, Chan C, Zhang HJ, Chen HL, Wong SS, Lau SK, Woo PC, et al: Delayed antiviral plus immunomodulator treatment still reduces mortality in mice infected by high inoculum of influenza A/H5N1 virus. Proc Natl Acad Sci USA 2008, 105:8091-8096.

42. Adams SC, Xing Z, Li J, Cardona CJ: Immune-related gene expression in response to $\mathrm{H} 11 \mathrm{~N} 9$ low pathogenic avian influenza virus infection in chicken and Pekin duck peripheral blood mononuclear cells. Mol Immunol 2009, 46:1744-1749.

43. Xing Z, Cardona CJ, Li J, Dao N, Tran T, Andrada J: Modulation of the immune responses in chickens by low-pathogenicity avian influenza virus H9N2. J Gen Virol 2008, 89:1288-1299.

44. Fitzgerald KA, McWhirter SM, Faia KL, Rowe DC, Latz E, Golenbock DT, Coyle AJ, Liao SM, Maniatis T: IKKepsilon and TBK1 are essential components of the IRF3 signaling pathway. Nat Immunol 2003, 4:491-496.

45. Kim MJ, Latham AG, Krug RM: Human influenza viruses activate an interferon-independent transcription of cellular antiviral genes: outcome with influenza A virus is unique. Proc Natl Acad Sci USA 2002, 99:10096-10101.

46. Zhang B, Li M, Chen L, Yang K, Shan Y, Zhu L, Sun S, Li L, Wang C: The TAK1-JNK cascade is required for IRF3 function in the innate immune response. Cell Res 2009, 19:412-428.

47. Grant CE, May DL, Deeley RG: DNA binding and transcription activation by chicken interferon regulatory factor-3 (chIRF-3). Nucleic Acids Res 2000, 28:4790-4799.

48. May DL, Grant CE, Deeley RG: Cloning and promoter analysis of the chicken interferon regulatory factor-3 gene. DNA Cell Biol 2000, 19:555-566.

49. Liniger M, Summerfield A, Zimmer G, McCullough KC, Ruggli N: Chicken cells sense influenza $A$ virus infection through MDA5 and CARDIF signaling involving LGP2. J Virol 2012, 86:705-717.

50. Flory E, Kunz M, Scheller C, Jassoy C, Stauber R, Rapp UR, Ludwig S: Influenza virus-induced NF-kappaB-dependent gene expression is mediated by overexpression of viral proteins and involves oxidative radicals and activation of IkappaB kinase. J Biol Chem 2000, 275:8307-8314.

51. Pahl HL, Baeuerle PA: Expression of influenza virus hemagglutinin activates transcription factor NF-kappa B. J Virol 1995, 69:1480-1484

52. Wang $X$, Hussain S, Wang EJ, Li MO, Garcia-Sastre A, Beg AA: Lack of essential role of NF-kappa B p50, RelA, and cRel subunits in virus-induced type 1 IFN expression. J Immunol 2007, 178:6770-6776.

53. Wei L, Sandbulte MR, Thomas PG, Webby RJ, Homayouni R, Pfeffer LM: NFkappaB negatively regulates interferon-induced gene expression and anti-influenza activity. J Biol Chem 2006, 281:11678-11684.

54. Kogut MH, Genovese KJ, He H, Kaiser P: Flagellin and lipopolysaccharide up-regulation of IL- 6 and CXCLi2 gene expression in chicken heterophils is mediated by ERK1/2-dependent activation of AP-1 and NF-kappaB signaling pathways. Innate Immun 2008, 14:213-222.

55. Kawai T, Akira S: Toll-like receptor and RIG-I-like receptor signaling. Ann N Y Acad Sci 2008, 1143:1-20.

56. Kim TK, Maniatis T: The mechanism of transcriptional synergy of an in vitro assembled interferon-beta enhanceosome. Mol Cell 1997, 1:119-129.

57. Kujime K, Hashimoto S, Gon Y, Shimizu K, Horie T: p38 mitogen-activated protein kinase and c-jun-NH2-terminal kinase regulate RANTES production by influenza virus-infected human bronchial epithelial cells. J Immunol 2000, 164:3222-3228.

58. Takeuchi O, Akira S: MDA5/RIG-I and virus recognition. Curr Opin Immunol 2008, 20:17-22.

59. Saito T, Owen DM, Jiang F, Marcotrigiano J, Gale M Jr: Innate immunity induced by composition-dependent RIG-I recognition of hepatitis $C$ virus RNA. Nature 2008, 454:523-527.

60. McNulty MS, Allan GM, Todd D, McFerran JB, McKillop ER, Collins DS, McCracken RM: Isolation of rotaviruses from turkeys and chickens: demonstration of distinct serotypes and RNA electropherotypes. Avian Pathol 1980, 9:363-375.

61. Lavrentieva IN, Medvedeva TE, Golubev DB: Characterization of the reproduction of influenza $\mathrm{A}$ epidemic viruses in cell cultures. Acta Virol 1986, 30:137-142.

62. Reed $L$, Muench $H$ : A simple method for estimating fifty percent endpoints. American Journal of Hygiene 1938, 27:493-497.

63. Kapczynski DR, Kogut MH: Measurement of avian cytokines with real-time RT-PCR following infection with the avian influenza virus. Methods $\mathrm{Mol}$ Biol 2008, 436:127-134
64. Rue CA, Susta L, Cornax I, Brown CC, Kapczynski DR, Suarez DL, King DJ, Miller PJ, Afonso CL: Virulent Newcastle disease virus elicits a strong innate immune response in chickens. J Gen Virol 2011, 92:931-939.

65. Morrison TB, Weis JJ, Wittwer CT: Quantification of low-copy transcripts by continuous SYBR Green I monitoring during amplification. Biotechniques 1998, 24:954-958. 960, 962.

doi:10.1186/1743-422X-10-342

Cite this article as: Jiang et al.: Transcription factor regulation and cytokine expression following in vitro infection of primary chicken cell culture with low pathogenic avian influenza virus. Virology Journal 2013 10:342.

\section{Submit your next manuscript to BioMed Central and take full advantage of:}

- Convenient online submission

- Thorough peer review

- No space constraints or color figure charges

- Immediate publication on acceptance

- Inclusion in PubMed, CAS, Scopus and Google Scholar

- Research which is freely available for redistribution

Submit your manuscript at www.biomedcentral.com/submit
C) Biomed Central 